ISSN 2693-2490

\title{
Chronic SJW pretreatment in the regulation of Cerebral Serotonergic and Behavioral Activity
}

Journal of Psychology and Neuroscience

Research Article

\author{
Mehnaz Gitay $^{1 *}$, Kausar Saboohi ${ }^{1,2}$, Bushra Chaudhary ${ }^{2}$ and Samina Bano ${ }^{1}$ \\ ${ }^{1}$ Clinical Biochemistry and Psychopharmacology research Unit, \\ Department of Biochemistry University of Karachi.Karachi-75270, \\ Pakistan \\ ${ }^{1}$ DOW University of Health Sciences Karachi, Karachi City, Sindh \\ 74200, Pakistan \\ *Correspondence author

\section{Dr. Mehnaz Gitay} \\ Clinical Biochemistry and Psychopharmacology research \\ Unit, Department of Biochemistry University of Karachi, \\ DOW University of Health Sciences \\ Karachi-75270 \\ Pakistan
}

${ }^{2}$ Biological and Biomedical Sciences, The Aga Khan University, Karachi,74800, Pakistan

Submitted : 08 Feb 2021 ; Published : 20 Apr 2021

\begin{abstract}
Background: Saint John's wort (SJW) is known for the medicinal powers of its leaves that are composed of a myriad of chemical components having diverse effects on various conditions like mild to moderately severe depressive disorders. Present study is carried out to explore the presynaptic adaptive measures resulting by the treatment with SJW prior to subjection of rats to forced swim test (FST).

Method: Adult Albino Wistar rats were divided into 2 groups (Saline and drug administered rats, $n=12$ each). Each group was further divided into stressed and unstressed groups $(n=6)$. SJW $(500 \mathrm{mg} / \mathrm{kg} / \mathrm{ml})$ was orally administered to the drug group for 28 days while saline was administered to the other group for the same period.

Results: Behavioral analysis of FST shows an increase in swimming time and a decrease in floating time of rats pretreated with SJW. Serotonin transporter (SERT) gene expression is decreased by SJW in both stressed and unstressed groups. SERT protein is increased by SJW in the unstressed group but decreased in the stressed group as compared to the saline administered group.

Conclusion: It can be concluded that SJW is affective in containing serotonergic hyperactivity simultaneously alleviating depression by mechanisms probably different to the serotonergic system.
\end{abstract}

Keywords: SJW, Serotonin, Depression, Herb, FST

Introduction

Saint John's Wort (SJW) is a perennial herb bearing bright yellow flowers, native to Europe, Western Asia and northern Africa. The aerial part of the plant is widely used for medicinal purposes, specially in the treatment of mild to moderate depression. The herb acts via the non-selective reuptake inhibition of nor-epinephrine, dopamine and serotonin, the action mediated by the increase in intracellular $\mathrm{Na}+[20,21]$. Apart from numerous similarities with other antidepressants, SJW has a unique action on the amino acid transmitters, glutamate and GABA [8;24,25]. Peak plasma levels of total hypericin were found to be attained after 4 hours of dosage (900-1800 mg) with concentrations ranging from $\mathrm{nM}$ to $\mu \mathrm{M}$, eliminated at a slower rate with a half-life of approximately 25 hours $[22,16,6]$. Hyperforin concentration in the range of $\mathrm{nM}$ is peaked in the plasma after 3.5 hours of dosage with steady state levels achieved within 3-4 days [4]. Suzuki and coworkers in 1984, for the first time reported the antidepressant activity of hypericum, attributing the action to the hypericin content of the herb that acted as a MAO inhibitor [23]. Since then the extracts of hypericum started to be standardized to this compound [18]. Later the flavonoid component was shown to have a potent MAO inhibitor activity [5]. Though all the active components of SJW are still not known, the antidepressant activity is attributed to hyperforin, hypericin, pseudohypericin and several flavonoids. It has been confirmed that SJW extract has a weak potency for MAO inhibition [9]. The enzyme inhibition is considered to be due to the flavonoid component of the herb, though the concentration is too low to show therapeutic effects $[17,14]$. Synaptosomal reuptake inhibition by SJW was also investigated and it was found that hyperforin inhibited the reuptake of monoamines (dopamine, serotonin and norepinephrine) at equal potencies with hypericin being inactive in all monoamine system $[12,19,15]$. Wonneman and his group in 2001 identified hyperforin as the reuptake inhibiting principle, but in the same study it was found that hyperforin free extracts also had the potential to inhibit reuptake in a weak or moderate manner [26]. Gobbi and colleagues, argued the direct interaction of SJW with the transporters on the 
basis that it did not alter [3H] citalopram binding, suggesting a rather, reserpine like mode of action for SJW [12]. It was concluded that the high synaptic concentrations of serotonin were an artifact of the excessive 5HT release due to SJW and the vesicle interactions. SJW exhibits its antidepressant activity within a dose range of $250-500 \mathrm{mg} / \mathrm{kg}$ [7, 3]. At a dose of $500 \mathrm{mg}, 2$ weeks SJW treatment showed no effect whereas 8 weeks treatment reduced Corticotropin releasing hormone (CRH) mRNA in the Paraventricular nucleus (PVN), indicating the involvement of SJW in the regulation of the HPA axis. Owing to the fact that not much research has been carried out integrating the peripheral and central actions of SJW, the exploration of the mechanism of action of SJW as well as its effect on serotonin transporter gene expression with a therapeutic dose $(500 \mathrm{mg} / \mathrm{kg})$ is ineluctable.

\section{Materials and Methods}

\section{Animals and Treatment}

All animal procedures described below were conducted in strict accordance with the national research council for the care and use of laboratory animals (1996).Ethical approval was obtained from institutional animal ethics committee. Locally bred Adult Albino Wistar rats (150-200 g) were housed 6 per cage under standard light and dark cycle at $25^{\circ} \mathrm{C} \pm 2{ }^{\circ} \mathrm{C}$ room temperature and were maintained on lab chow and water ad libitum. All experiments were carried out in the light phase of the cycle and were carried out with minimum suffering to the animals. Rats were checked for open field locomotor activity. SJW (500 mg/ $\mathrm{kg} / \mathrm{ml}$ ) was orally administered to the test group for 4 weeks. An equal volume of saline was given to the controls. Rats were decapitated on the day following treatment completion. The rats of the FST group were made to swim before decapitation. Serum and brains were collected and stored at $-20^{\circ} \mathrm{C}$ and $-70^{\circ}$ $\mathrm{C}$ respectively, until analysis.

\section{Forced Swim Test (FST)}

Locally bred Albino Wistar rats were exposed to forced swim test as described in detail [2]. Behavior during test swimming session was scored using a time sampling method [10]. Every 5 seconds; one of the 3 behaviors was recorded. Immobility was scored when the animal was making movements sufficient just to stay afloat. Swimming was scored when the animal actively swam around the tank $(46 \mathrm{~cm}$ high and $20 \mathrm{~cm}$ inner diameter) filled with $30 \mathrm{~cm}$ water (temperature $21^{\circ} \mathrm{C} \pm 2^{\circ} \mathrm{C}$ ), making movement greater than those necessary to stay afloat. Climbing was scored when the animal made vigorous thrashing movements with its fore paws, usually directed against the sides of the tank. Behavioral activity was videotaped and the results are shown as the total time in seconds for each behavioral category.

\section{Chemicals and drugs}

SJW was a kind gift from medics pharma. All chemicals were of the highest analytical grade.

\section{Quantification of SERT mRNA expression}

To quantify SERT mRNA isolated from the brain stems, the tissues were weighed and accordingly homogenized in appropriate volumes of Trizol $^{\circledR}$ reagent (Invitrogen) for isolation of total RNA. DNase 1 digestion was performed and the RNA was purified with chloroform followed by isopranol precipitation of RNA. The quantity and integrity of the RNA was checked with the nanodrop (ND 1000) and $1 \mu \mathrm{g}$ of RNA was used for reverse transcription. Reverse transcription was done with superscript III (Invitrogen), by adding the RNA, primers and dNTPs $(10 \mu \mathrm{l})$ to a nuclease free tube. Mixture was heated for 5 minutes at $650 \mathrm{C}$ and chilled on ice. $10 \mu \mathrm{l}$ of cDNA synthesis mix that comprises of 10x RT buffer, $\mathrm{MgCl}$, 0.1M DTT, RNase OUT and Superscript III is added to the mixture. The contents were mixed gently and incubated at $50^{\circ} \mathrm{C}$ for 50 minutes, then at $85^{\circ} \mathrm{C}$ for 5 minutes to terminate the reaction. RNase $\mathrm{H}, 1 \mu \mathrm{l}$ was then added and incubated at $37^{\circ} \mathrm{C}$ for 20 minutes. Reported primers from Abumaria, 2006 were used [1]. Amplicons were amplified in the BioRad c1000 thermocycler using Go Taq ${ }^{\circledR}$ qPCR Master Mix (Promega). The components of the reaction mixture are given below in the table. The real time cycler conditions are as follows: $95^{\circ} \mathrm{C}$ for 2 minutes, cycling steps $-95^{\circ} \mathrm{C}$ for 15 seconds, $55^{\circ} \mathrm{C}$ for 1 minute, back again to the initial step of the cycle, i.e $95^{\circ} \mathrm{C}$ for 15 seconds. The cycle continued 40 times, resulting in 60 meramplicons for SERT and 83 mer amplicons for GAPDH.

\begin{tabular}{|l|l|l|}
\hline Name of Gene & Forward Primer & Reverse Primer \\
\hline SERT & $\begin{array}{l}\text { TCTGAAAAG } \\
\text { CCCCACTGGACT }\end{array}$ & $\begin{array}{l}\text { TAGGACCGTGT } \\
\text { CTCATCAGGC }\end{array}$ \\
\hline GAPDH & $\begin{array}{l}\text { TGCCCCCATG } \\
\text { TTTGTGATG }\end{array}$ & $\begin{array}{l}\text { TGGTGGTGC } \\
\text { AGGATGCATT }\end{array}$ \\
\hline
\end{tabular}

\section{Western Blotting}

Total protein extracts from the brain stem were obtained from the phenolic phase of the Trizol homogenates after RNA isolation according to manufacturer's instructions. Samples from each group were pooled and proteins were precipitated with isopropyl alcohol and then washed with $0.3 \mathrm{M}$ guanidine hydrochloride in $95 \%$ ethanol. The pellet was dissolved in $1 \%$ SDS with incubation at $50^{\circ} \mathrm{C}$ for 5 to 10 minutes. The proteins were quantitated with modified Lowry Method and 200 $\mu \mathrm{g}$ of proteins/well was used for SDS PAGE. Proteins were separated in a $10 \%$ SDS-polyacrylamide gel and transferred to Polyvinylidene difluoride membranes (PVDF-cat \# Z310204-6EA, Sigma). The resulting blots were then probed with antibodies against SERT (Millipore: anti-Serotonin Transporter-cat \# AB1594P) for 12 hours and bands were visualized after color development with NBT/BCIP. Two SDS PAGE gels were run simultaneously, in order to compare the location of the bands on the membrane (band size) on the protein marker of the simultaneous gel. JPEG images were viewed and compared with Adobe Photoshop according to the band intensities, and contrast adjustments were made [13].

\section{Statistical Analysis}

All results were expressed as mean \pm standard error of mean (SEM). Data was analyzed using two way ANOVA followed by Newman Keul's q-test and by student's t test where appropriate. $\mathrm{P}<0.05$ was considered statistically significant. 
The analysis was carried out using SPSS software of version 19.

\section{Results}

Figure 1: Data analyzed by Student's t-test show that SJW administration significantly elevates swimming time $(\mathrm{P}=0.01)$ with no effect on climbing time $(\mathrm{P}=0.0 .49)$ and a significant decrease in floating time $(\mathrm{P}=0.042)$.

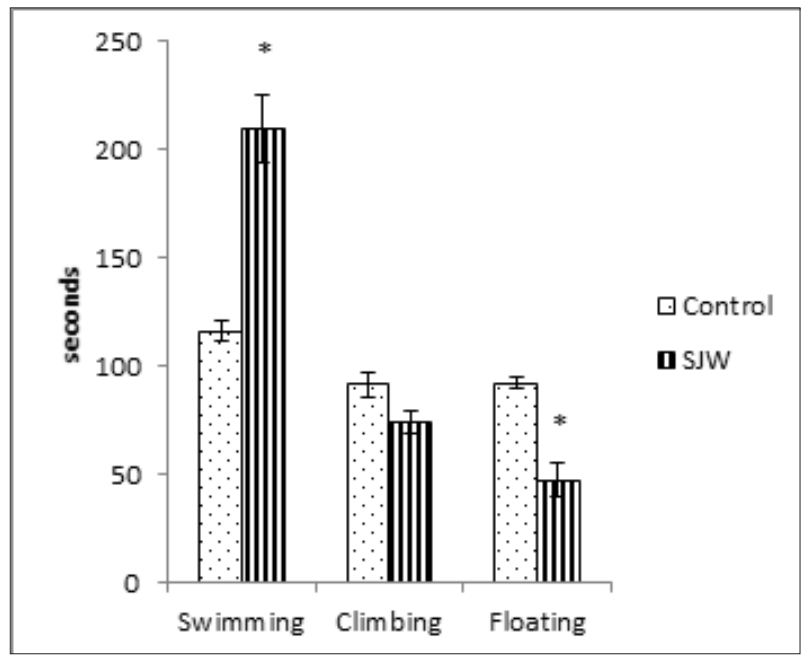

Figure 1: Effect of Chronic SJW administration on FST behavior. Values are means \pm SEM for each group of 6 rats. The significance of the differences is indicated by $* \mathrm{P}<0.05$ when stressed group is compared with respective control and $\dagger \mathrm{P}<0.05$ when drug treated group is compared with similarly treated vehicle control.

Figure 2 shows the SERT gene expression in the brain stem region as a percentage of the housekeeping gene GAPDH expression. Data analysis using 2 way ANOVA indicates the effect of FST ( $\mathrm{F}=4.61, \mathrm{P}=0.044)$, SJW ( $\mathrm{F}=154.07, \mathrm{P}=0.0005)$ and FST $x$ SJW $(\mathrm{F}=58.60, \mathrm{P}=0.0005)$ to be significant.

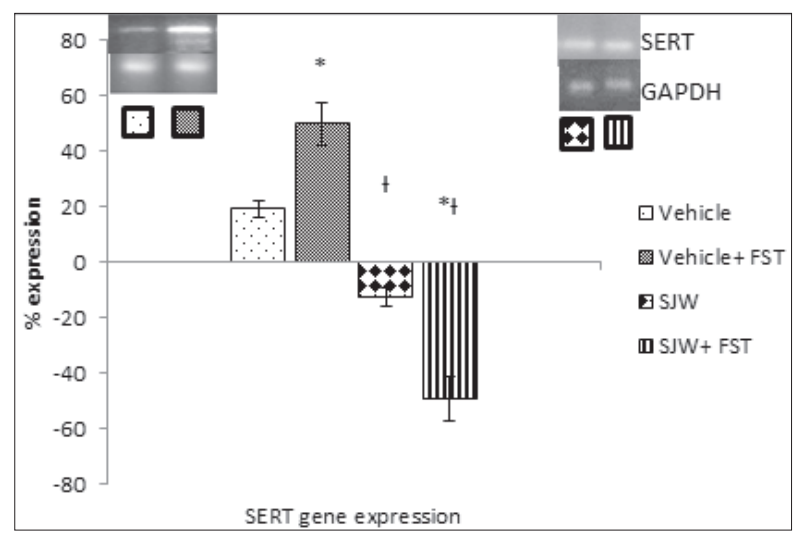

Figure 2: Effect of chronic SJW administration on SERT gene expression in the brain stem. Values are means \pm SEM for each group of 6 rats. Data was analyzed by 2 -way ANOVA, followed by Newman-Keul's q- test. The significance of the differences is indicated by $* \mathrm{P}<0.05$ when stressed group is compared with respective control and $\uparrow \mathrm{P}<0.05$ when drug treated group is compared with similarly treated saline control.
Table 1 shows that the SERT proteins were 0.94 times less in the brain stem of drug+FST exposed rats as compared to the SJW treated rats. The drug increased SERT (1.05 times) as compared to saline.

\begin{tabular}{|l|l|}
\hline Group & Intensity as compared to saline control \\
\hline FST & +1.98 \\
\hline SJW & +1.05 \\
\hline SJW FST & -0.94 \\
\hline
\end{tabular}

Table 1: The amount of SERT protein in the brain is estimated as the ratio of intensity with photoshop

\section{Discussion}

Anti-anxiety effects of SJW are seen with 2 weeks treatment as reduced climbing time. Garg and coworkers in 2010 [11], have proven the anti-anxiety effects of SJW on human subjects supporting the anti-anxiety property of SJW, where potent antianxiety effects were observed after 6 weeks. On the contrary, current study showed no effect on the anxiety system beyond 2 weeks. 4 weeks treatment shows effective antidepressant activity as seen by elevated swimming time, suggesting therapeutic effectiveness of SJW to be attained not before 4 weeks .SJW had no effect on the locomotor activity of the rats with any of the designed chronic treatments.

Treatment of rats with SJW for 4 weeks significantly decreases SERT gene expression, an effect due to FST as well as SJW. Although in the absence of SJW, FST enhances the expression of SERT, the combined effect of stress and SJW is to decrease it. Studies with $3[\mathrm{H}]$ Citalopram have shown the inability of SJW to block the serotonin transporters [12]. Thus, SJW may be considered effective in modulating the reuptake at the gene expression level. Consequent to 4 weeks SJW treatment, SERT protein is highly present in the brain stem. Prophylactically treated rats with SJW for 4 weeks, later subjected to FST show a decrease in brain stem SERT proteins. Owing to the subsequent decrease in serotonin synthesis with an increase in brain stem SERT, the decrease in brain stem SERT in FST ensures enhanced serotonin synthesis. Although SJW decreases SERT gene expression in both stressed and unstressed groups, the decrease in the SERT expression was greater in the former group. These results call for the conclusion that in presence of SJW, FST induced enhanced gene expression not only declines, but is also trafficked in a manner that regulates serotonin synthesis to alleviate the effects of stress. Consequent to Chronic SJW administration SERT gene expression is down regulated though the transporter activity seems to be enhanced, in response to the enhanced firing rate. Due to stress the transporters in the brain stem are reduced, probably trafficked to the terminals for reuptake.

\section{References}

1. Abumaria N, Rygula R, Hiemke C, Fuchs E, HavemannReinecke U, Ruther E, Flugge G (2007) Effect of chronic citalopram on serotonin-related and stress- 
regulated genes in the dorsal raphe nucleus of the rat. Eur Neuropsychopharmacol 17: 417-429.

2. Bano S, Morgan CJ, Badawy AAB, Buckland PR and Mcguffin P (1999) Inhibition of rat liver tryptophan pyrrolase activity by fluoxetine, Pakistan Journal of Pharmaceutical Science, 12(2) : 11-16.

3. Bhattacharya S K, Chakarabarti A, Chattergee S S (1998) Activity profiles of two hyperforin-containing hypericum extracts in behavioral models. Pharmacopsychiatry 31 (Suppl. 1): 22-29.

4. Biber A, Fischer H, Romer A, Chatterjee S S (1998) Bioavailability of hyperforin from hypericum extracts in rats and human volunteers. Pharmacopsychiatry 31 (Suppl. 1): 36-43.

5. Bladt S, Wagner H (1994) Inhibition of MAO by fractions and constituents of hypericum extract. J Geriat Psychiat Neurol 7(Suppl. 1): 57-59.

6. Brockmoller J, Reum T, Bauer S, Kerb R, Hubner W D, Roots I (1997) Hypericin and pseudohypericin: pharmacokinetics and effects on photosensitivity in humans. Pharmacopsychiatry 30 (Suppl. 2): 94-101.

7. Butterweck V, Wall A, Lieflander-Wulf U, Winterhoff H, Nahrstedt A (1997) Effects of the total extract and fractions of Hypericum perforatum in animal assays of antidepressant activity. Pharmacopsychiatry 30 (Suppl. 2): $117-124$.

8. Chatterjee S S, Bhattacharya S K, Wonnenmann M (1998) Hyperforin as a possible antidepressant component of hypericum extracts. Life Sci 63: 499-510.

9. Cott JM. (1997) In vitro binding and enzyme inhibition by Hypericum perforatum extract. Pharmacopsychiatry; 30 Suppl. 2:108-12.

10. Detke MJ, Rickels M, Lucki I (1995) Active behaviors in the rat forced swimming test differentially produced by serotonergic and noradrenergic antidepressants. Psychopharmacology, 121: 66-72.

11. Garg K, Gupta A, Rao HK, Sharma K (2010) Efficacy of Hypericum Perforatum (St. John's Wort) in patients of hypertension with associated anxiety. Journal of Herbal Medicine and Toxicology, 4 (1): 103-108.

12. Gobbi M, Valle FD, Ciapparelli C, Diomede L, Morazzoni P, Verotta L, Caccia S, Cervo L, Mennini T. (1999) Hypericum perforatum L. extract does not inhibit 5-HT transporter in rat brain cortex. Naunyn Schmiedebergs Arch Pharmacol; 360(3): 262-269.

13. Guerzoni C, Bardini M, Mariani SA, Ferrari G-Amorotti, Neviani $\mathrm{P},(2006)$ Inducible activation of CEBPB, a gene negatively regulated by $\mathrm{BCR} / \mathrm{ABL}$, inhibits proliferation and promotes differentiation of $\mathrm{BCR} / \mathrm{ABL}$-expressing cells. blood. 107: 4080-4089 (WESTERN BLOTTING PROCEDURE)

14. J“urgenliemk G, Nahrstedt A. (2002) Phenolic compounds from Hypericum perforatum. Planta Med; 68: 88-91.

15. Jensen AG, Hansen SH, Nielsen EO (2001) Adhyperforin as a contributor to the effect of Hypericum perforatum L. in biochemical models of antidepressant activity. Life Sci ; 68: 1593-1605.

16. Kerb R, Brockmoller J, Staffeldt B, Ploch M, Roots I
(1996) Singledose and steady-state pharmacokinetics of hypericin and pseudohypericin. Antimicrob Agents Chemother 40: 2087-2093.

17. Nahrstedt A (2000) Antidepressant constituents of Hypericum perforatum. In: Chrubasik S, Roufogalis BD, editors. Herbal medicinal products for the treatment of pain. Lismore: South-Cross University Press, 2000: 144153.

18. Nathan PJ (2001) Hypericum perforatum (St John's Wort): a non-selective reuptake inhibitor? A review of the recent advances in its pharmacology. Journal of Psychopharmacology 15(1): 47-54.

19. Neary, J. T., Whittemore, S. R., Bu, Y., Mehta, H., \& Shi, Y. F. (2001) Biochemical mechanisms of action of Hypericum LI 160 in glial and neuronal cells: inhibition of neurotransmitter uptake and stimulation of extracellular signal regulated protein kinase.Pharmacopsychiatry; 34 Suppl. 1: S103-S107.

20. Singer A, Wonnemann M, Muller WE (1999) Hyperforin, a major antidepressant constituent of St John's Wort inhibits serotonin reuptake by elevating free intracellular $\mathrm{Na}^{+}$. J Phar Exp Therapeut 290: 1363-1368.

21. Singer A, Wonnemann M, Muller W E (2000) Hyperforin alters free intracellular $\mathrm{H}^{+}$and $\mathrm{NA}^{+}$concentration in human platelets. Proceedings of the Biocenter Symposium on Drug Therapy: pharmacology of St John's Wort (Hypericum perforatum L.) and its constituents. University of Frankfurt, Germany.

22. Staffeldt B, Kerb R, Brockmoller J, Ploch M, Roots I (1994) Pharmacokinetics of hypericin and pseudohypericin after oral intake of the hypericum extract LI 160 in healty volunteers. J Geriatr Psychiatr Neurol, 7: S39-S53.

23. Suzuki O, Katsumata Y, Oya M (1984) Inhibition of monoamine oxidase by hypercin. Planta Medica, 50: 272-274.

24. Wonnemann M, Singer B, Muller W E (2000a) Inhibition of synaptosomal uptake of $3 \mathrm{H}$-glutamate and 3H-GABA by hyperforin, a major constituent of St John's Wort. Proceedings of the Biocenter Symposium on Drug Therapy: pharmacology of St John's Wort (Hypericum perforatum L.) and its constituents. University of Frankfurt, Germany.

25. Wonnemann M, Singer B, Muller W E (2000b) Inhibition of synaptosomal uptake of $3 \mathrm{H}$-glutamate and $3 \mathrm{H}-\mathrm{GABA}$ by hyperforin, a major constituent of St John's Wort: the role of amiloride sensitive sodium conductive pathways. Neuropsychopharmacology, 23: 188-197.

26. Wonnemann M, Singer A, Siebert B,Muller WE (2001) Evaluation of synaptosomal uptake inhibition of most relevant constituents of St John's wort. Pharmacopsychiatry, 2001; 41 Suppl. 1: S148-S151.

Copyright: (C2021 Dr. Mehnaz Gitay. This is an open-access article distributed under the terms of the Creative Commons Attribution License, which permits unrestricted use, distribution, and reproduction in anymedium, provided the original author and source are credited. 